\title{
The Analysis of Some Indicators of Oxidative Student's Stress with An Initial-I Stage of Generalized Periodontitis
}

\author{
Tetiana Pavliuk ${ }^{*}$, Mykola Rozhko
}

\begin{abstract}
Periodontal tissue disease is one of the most widespread human diseases. The development of periodontal tissue diseases (generalized periodontitis) depends on many local and systemic risk factors. An important place is the emergence of diseases of periodontal tissues against the background of a violation of the normal functioning of antioxidant defense systems, which leads to the development of oxidative stress and dysfunction of cells and tissues of the oral cavity. The aim of the study was to determine some indicators of oxidative stress in 2-year students of a medical university with an initial-I degree of generalized periodontitis. To assess the level of oxidative stress, indicators such as malonic aldehyde (MDA), SOD (superoxide dismutase) and glutathione peroxidase were used. The results of the study showed that oxidative stress plays an important role in the pathogenesis of periodontal tissue diseases.
\end{abstract}

Keywords

generalized periodontitis; oxidative stress; medical students

Ivano-Frankivsk National Medical University, Ivano-Frankivsk, Ukraine

*Corresponding author: pavliuktv@gmail.com

\section{Problem statement and analysis of the latest research}

Periodontitis is a multifactorial chronic irreversible inflammatory disease that affects the retaining structures of teeth that initiated and distributed through a complex interaction between parodonto-pathogenic microorganisms and the protective system of the organism $[1,2]$.

According to WHO, periodontal disease affection was detected in $80 \%$ of children and $95 \%$ of adult population in our planet. Periodontal disease is one of the most widespread human diseases [3]. Gingivitis and generalized periodontitis are the most common inflammation affection that destroys periodontal tissues (cellular bone) and subsequent tooth loss. Today, there is no country or region in the world where there is no periodontal disease $[4,5]$.

The development of periodontal tissue diseases (generalized periodontitis) depends on many local or systemic risk factors. An important place is given to parodonto-pathogenic microorganisms that induce an increase level of proinflammatory cytokines with the subsequent destruction of periodontal tissues. The most common is Porphyromonas gingivalis, Prevotella intermedia, Aggregatibacter actinomycetemcomitans $[5,6]$.

However, it is not enough parodonoto-pathogenic bacteria for development and progression periodontal tissue diseases. Possible risk factors are age, tobacco use, systemic diseases, psychological stress, etc. [5, 7].
Several studies have shown a correlation between psychological stress and inflammatory diseases, such as rheumatoid arthritis and generalized periodontitis $[8,9]$.

Periodontal tissues diseases occur in the background of a violation of normal functioning of antioxidant defense systems, which leads to the development of oxidative stress and dysfunction of cells and tissues of oral cavity. It is believed that the enhancement of peroxide oxidation processes indicates a violation between protective and adaptive reactions of the organism at the cellular level and homeostasis in general [10].

The level of lipid peroxidation (LPO) products increases dramatically in pathological processes, that leads to violation of structural and functional organization of membranes. It was also determined that the LPO is under the control of the physiological antioxidant system (AOS), one of its components being superoxide dismutase (SOD) [11].

An important role in the pathogenesis in majority of respiratory diseases, including the oral cavity, is oxidative stress (OS), the main cause of which is an imbalance in the system of "oxidants-antioxidants", which is expressed by excessive formation of active forms of oxygen (AFO) and efficiency attenuation of antioxidant protection (AOP) [12].

The enhancement of peroxide oxidation processes as a result of the accumulation of AFO is a non-specific response of cells to the effects of negative factors, which results in oxidative stress in them. Excess of AFO in cells causes the 
destruction of lipids, proteins and nucleic acids, resulting in the accumulation of peroxide oxidation products. The increase of AFO activates the antioxidant defense system, that allows living organisms to maintain an oxidation-antioxidant balance and adapt to changing conditions of existence $[10,13,14]$.

The objective of the work

To determine some indicators of oxidative stress in the $2^{\text {nd }}$ year students, who study at medical university with an initial-I stage of generalized periodontitis.

\section{Materials and Methods}

We examined 120 students, who study the $2^{\text {nd }}$ year of medical university from the age of 18 to 25 years. For the study of oxidative stress indicators, we selected 25 students with initialI stage of generalized periodontitis (GP) (II group), and 15 clinically healthy patients (control group I).

The diagnosis of generalized periodontitis of the initial-I stage of severity was based on data from an objective study, clinical indices of the PMA indices (papillary-marginal-alveolar index), PI (Ramfjord periodontal index), BI (index of gum bleeding with the help of H.R. Muchlemann, S. Soon, modified by I. Cowell) and the Green-Vermillion (OHI-S) index. We used M.F. Danilevsky classification for putting periodontal tissue diseases' diagnosis.

The control group consisted of periodontologically healthy students who had good oral hygiene, lack of signs of gum inflammation (bleeding during probing, hyperemia and edema), periodontal pockets, or tooth mobility.

To assess the level of oxidative stress there were used such indicators as malondialdehyde (MDA), SOD and glutathione peroxidase.

The mouth fluid was used as a material for research, that was taken in the morning. All students did not eat, drink or smoke before giving biological material.

Students with systemic diseases, students who had periodontal treatment, who took medication (antibiotics, antiinflammatory or other medications during the last six months) or had bad habits (smoking, alcohol, etc.) did not participate in the study.

The statistical analysis of the research results was carried out using the statistical package "Stat Soft 6.0", the classical methods of variation statistics. The difference between the studied indicators was estimated according to Student's criterion.

\section{Results and Discussion}

According to results of laboratory examination of oral fluids in students of second year of medical university, the following results were obtained.

In the study of malondialdehyde (Fig. 1) in the oral liquid, we have observed that this indicator in group I, which includes clinically healthy students, was $0.21 \pm 0.01 \mathrm{nmol} / \mathrm{ml}$. In the II group, where there were students with initial-I stage of GP, MDA is significantly higher and equal $0.81 \pm 0.06 \mathrm{nmol} / \mathrm{ml}$, which is statistically confirmed ( $p<0.001)$. As you can see MDA is higher in students with GP, that indicate the presence of oxidative stress. This result is also confirmed by Panjamurthy K. and other studies [16].

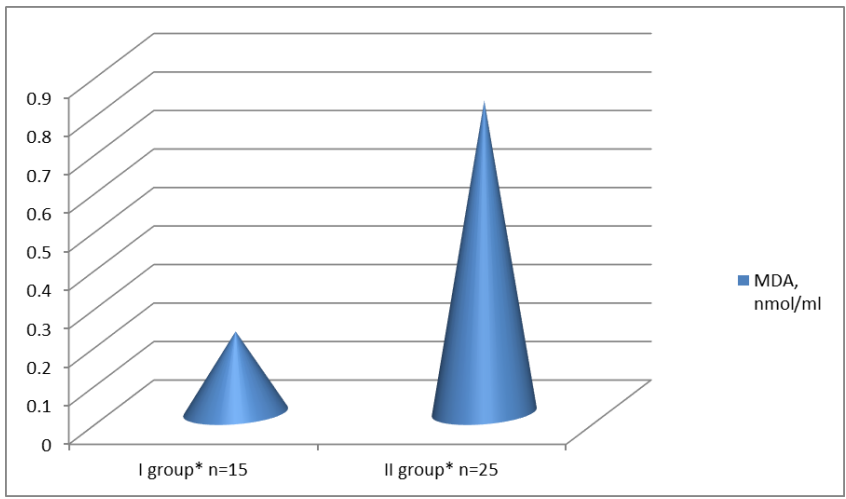

Figure 1. The correlation of MDA in the oral liquid between the examined in the I and II groups

Note. * - the likelihood of differences in MDA score in groups I and II according to Student's criterion, $\mathrm{p}<0.001$.

The analysis of antioxidant system also showed significant changes in SOD and glutathione peroxidase.

Considering the amount of SOD (Fig. 2) in the oral liquid, it was noted that the value of the indicator in group I is significantly higher $(45.73 \pm 2.13 \mathrm{U} / \mathrm{mg}$ protein $)$ compared to the second group, where the figure is $23,56 \pm 0.89 \mathrm{U} / \mathrm{mg}$ protein $(\mathrm{p}<0.001)$.

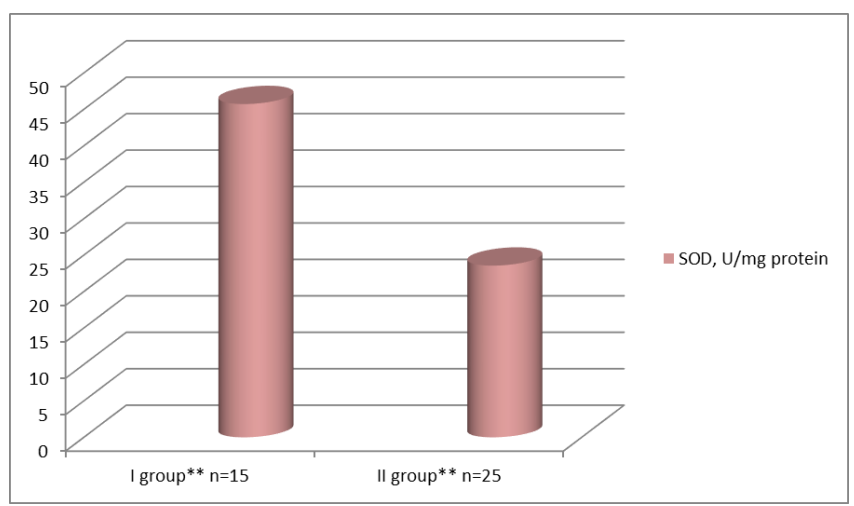

Figure 2. The correlation of SOD in the oral liquid between examined I and II groups

Note. $* *$ - the likelihood of differences in SOD indicator in groups I and II according to Student's criterion, $\mathrm{p}<0.001$.

The glutathione peroxidase (Fig. 3) is significantly lower in group II $(0.16 \pm 0.08 \mathrm{nmol} / \mathrm{mg}$ protein $)$ in relation to group I $(0.33 \pm 0.02 \mathrm{nmol} / \mathrm{mg}$ protein $)$, which is statistically significant $(\mathrm{p}<0.05)$.

The data of antioxidant system activity (SOD and glutathione peroxidase) is lower in periodontal tissue diseases than in young people with a healthy gums. This indicates a 


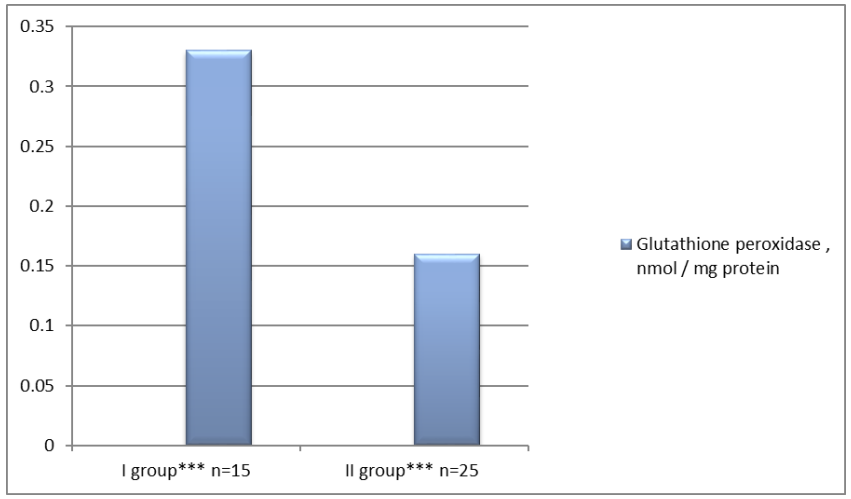

Figure 3. The correlation of glutathione peroxidase in the oral liquid between examined I and II groups

Note. $* * *$ - the likelihood of differences in the glutathione peroxidase index in I and II groups according to Student's criterion, $\mathrm{p}<0.05$.

violation of the physiological balance between the AFO and antioxidants, which is the reason for the occurrence of GP.

The results of decreased activity of SOD and glutathione peroxidase in the oral liquid were also demonstrated by Conakci studies and others. [16].

\section{Conclusions}

Based on the obtained results, it was concluded that generalized periodontitis is accompanied by oxidative stress. This is confirmed by increase in the index of lipid peroxidation (malondialdehyde) and a decrease in the antioxidant system (SOD, glutathione peroxidase). The results also indicate that there are significant relationships between the oxidant status and the state of periodontal tissues. According to the obtained data, oxidative stress plays an important role in the pathogenesis of periodontal tissue diseases.

\section{Prospects of Further Researches}

We are planning further study of the prooxidant and antioxidant system parameters in oral fluids of senior students.

\section{Conflict of Interest}

The authors stated no conflict of interest.

\section{References}

[1] AlMoharib HS, AlMubarak A, AlRowis R, Geevarghese A, Preethanath RS, Anil SJ. Oral fluid based biomarkers in periodontal disease: part 1. Saliva. Journal of International Oral Health. 2014;6(4):95-103. [PMid:25214743 PMCid:PMC4148585]

[2] Almerich-Silla JM, Montiel-Company JM, Pastor S, Serrano F, Puig-Silla M, Dasí F. Oxidative Stress Parameters in Saliva and Its Association with Periodontal Diseases and Types of Bacteria. J Disease Markers [Internet]. 2015. Available from: http://dx.doi.org/10.1155/2015/653537 DOI: 10.1155 / 2015/653537 DOI: https://doi. org/10.1155/2015/653537

[3] Zadik Y, Bechor R, Shockat Z, Galor S. Ethnic origin and alveolar bone loss in Israeli adults in Hebrew. Refuat Hpeh vehashinayim. 2008;25(2):19-22.

[4] Buatongsri V, Songpaison Y, Hong Prasong N, Phantumvanti P, Clark N. Distribution of pf severe periodontitis in urban (Bankok) and rural (payao province) high risk to stress group of this population. Cu Dent J. 2002;25:1-4.

[5] Konovalova OV. Influence of psychoemotional stress on the state of periodontal tissues (review of literature). Bulletin of Biology and Medicine. 2016;1(133):36-40.

[6] Castillo DM, Sanchez-Beltran MC, Castellanos JE, Sanz I, Mayorda-Fayad I, Sanz M et al. Detection of specific periodontal microorganisms from bacteriemia samples after periodontal therapy using molecular-based diagnostics. J Clin Periodontol. 2011;38:418-427. DOI: https://doi.org/10.1111/j.1600-051x. 2011.01717.x [PMid:21392048]

[7] Cronin AJ, Claffey N, Stassen LF. Who is at risk? Periodontal disease risk analysis made available to the general dentist. Br Dent J. 2008;205(3):131137. DOI: https://doi.org/10.1038/s j.bdj. 2008.653 [PMid:18690185]

[8] Reners M, Breex M. Stress and Periodontal Disease. Int J Dent Hyg. 2007;5(4):199-204. DOI: https : / / doi . org/10.1111/j.1601-5037.2007.00267.x [PMid:17927631]

[9] Rivera C, Monsalve F, Suazo I, Becerra J. Stress increases periodontal inflammation. Exp Theor Med [Internet]. Nov. 2012;4(5):883-888. Available from: https: //www.ncbi.nlm.nih.gov/pmc/articles/PMC3493748/ DOI: 10.3892 / enm.2012.675.

[10] Neporoda KS, Berehova TV, Sukhomilin AA, Gordienko LP, Mykytenko AO. Development of oxidative stress of the organs of the oral cavity under different conditions (review of literature). Southeastern Medical Journal. 2017;18(18):81-84.

[11] Pinda MY, Yakymets MM, Karkinska GB. Indicators of homeostasis of the cavity of the mouth in 6-year-old children with high intensity of caries of teeth. Bulletin of Biology and Medicine. 2014;4(116):354-356.

[12] Litvinets LJ. Oxidative stress and antioxidant protection in children with varying degrees of bronchial asthma control. Child health. 2013;8(51):71-74. 
[13] Armstrong D. Oxidative Stress Biomarkers and Antioxidant Protocols. Totowa, New Jersey: Humana Press Inc.; 2002.186p. DOI: https : / doi .org/10. $1385 / 1592591736$

[14] Vladyka AS, Levytsky ER, Poddubnaya LP. Medium molecules and the problem of endogenous intoxication in critical states of different etiologies. Anesthesiology and Reanimatology. 1987;2:17-19.

[15] Panjamurthy K, Manoharan S, Ramachandran CR. Lipid peroxidation and antioxidant status in patients with periodontitis. Cell Mol Biol Lett. 2005;10:255-264. [PMid:16010291]

[16] Canakci CF, Cicek Y, Yildirim A, Sezer U, Canakci $\mathrm{V}$. Increased levels of 8-hydroxydeoxyguanosine and malondialdehyde and its relationship with antioxidant enzymes in the saliva of periodontitis patients. Eur J Dent. [Internet]. April 3, 2009(3):100-6. Available from: https://www.ncbi.nlm.nih.gov/pubmed/19421389. [PMid:19421389 PMCid:PMC2676068]

Received: 2018-11-12

Revised: 2018-11-21

Accepted: 2018-11-21 